\title{
Influences of Parity, Body Weight, Milk Yield and Suckling Stimulation on the Interval from Calving to First Ovulation in Beef Cows
}

\author{
Yoshiaki Izaike, Osamu Suzuki, Kazuhiro Shimada, Akira Okano*, \\ Takao Oishi* and Motoaki KosugiYama \\ Department of Animal Industry, Chugoku National Agricultural \\ Experiment Station, Ohda-shi Shimane 694 \\ *National Institute of Animal Industry, Tsukuba-Norindanchi, \\ P.O. Box 5, Ibaraki 305
}

(Accepted for publication August 12, 1988)

\begin{abstract}
Summary. This experiment was conducted to examine the effects of parity, body weight changes, milk yield and suckling stimulation on Japanese Black cows using 66 postpartum first ovulation records. The multiple regression equations using backward procedure for estimating the recurrence interval of postpartum first ovulation are as follows.

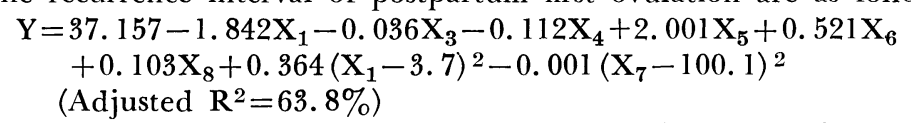

where, $Y$ : Days from calving to first ovulation, $\mathrm{X}_{1}$ : Parity, $\mathrm{X}_{3}$ : Body weight just after calving $(\mathrm{kg}), \mathrm{X}_{4}$ : Body weight loss from just after calving to 30 days postpartum $(\mathrm{kg})$, $\mathrm{X}_{5}$ : Milk yield at 30 days postpartum $\left(\mathrm{kg} /\right.$ day), $\mathrm{X}_{6}$ : Suckling events at 30 days postpartum (times/day), $\mathrm{X}_{7}$ : Total suckling time at 30 days postpartum $\left(\mathrm{min} /\right.$ day), $\mathrm{X}_{8}$ : Frequency of suckling interval time $(\%)$.

The relative importance of the variables' order was $\mathrm{X}_{1}>\mathrm{X}_{5}>\mathrm{X}_{4}>\mathrm{X}_{3}>\mathrm{X}_{7}>\mathrm{X}_{8}>\mathrm{X}_{6}$. In this analysis, increasing of milk yield and the number of suckling events indicated inhibitory effects on the occurrence of first ovulation, and body weight changes affected as well as the effects of parity, milk yield and suckling stimulation. KEY wORDS; FIRST OVULATION, PARITY, BODY WEIGHT, MILK YIELD, SUCKLING STIMULATION, BEEF COW.
\end{abstract}

Jpn J Anim Reprod 34, 209-218, 1988

肉用牛における分婏後の初回排卵までの日数に 及ぼす産次, 体重, 哺乳量, 哺乳刺激の影響



農林水産省中国農業試験場畜産部, $\mathbf{T} 694$ 島根県大田市川合町吉永 60

1）現 農林水産省畜産試験場, $\mathbf{T} 305$ 茨城県稲敷郡茎崎町池の台 2

一般に, 肉用繁殖雌牛の分娩から発情回帰までの日数 は長く, そのばらつきも大きいことから繁殖管理上多く の問題を抱えている。牛の分娩後の卵巣機能回復には, 産次 (Wiltbank and Cook, 1958; 居在家ら, 1984),
栄養状態 (Dunn et al., 1969; 岩崎, 1986), 哺乳 (Reeves and Gaskins, 1981; 鈴木・佐藤, 1984), 分娩季節 (Bulman and Lamming, 1978) などの多くの要因の影 響を受ける。また，これらの要因は相互に関連性を有し 
ていることから，その解明を一層複雑なものとしてい る。分娩間隔を短縮し, 生産性を向上させるためには, 分娩後の繁殖機能回復に及ぼす要因の解析が必要であ る。

また，肉用牛において哺乳頻度の増加は初回発情まで の期間を長くすることが報告されている (Wyatt et al., 1977)。この報告から, 産子による哺乳刺激は母牛の分 娩後の卵巣機能回復に密接に関連しているものと推察さ れる。しかし, 肉用牛は分娩後 $4 \sim 8$ か月間は産子に自 然哺乳させているのが一般的であり, 哺乳行動や哺乳量 等の違いと分娩後の卵巣機能回復との関連性については 明らかにされていない。

そこで, 本研究は重回帰分析の手法を用いて, 分娩後 の初回排卵までの日数に及ぼす産次, 分婏季節, 体重の 変動, 哺乳量, 哺乳回数なぞの影響について検討し, そ れぞれの要因の特性を明らかにしようとした。

\section{材料と方法}

\section{供試牛と卵巣状龍の調査}

初産から 9 産次を正常分婏した, 黒毛和種繁殖牛37頭 の延べ66分姢頭数について供試した。供試牛は分婏予定 日の約10日前に放牧草地から開放牛舎に移し，1頭当た

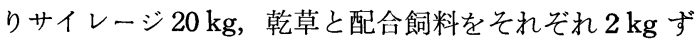
つ給与した。体重は分姢直後と，その後は毎週 1 回定期 的に測定した。分婏後30日目の体重は, その前後の测定 日の間に直線回帰を当てはめて算出した。卵巣の状態は 分娩後約 7 日目から週に 2 回, 直腸検査により調べた。 排卵が予想される場合は連日直腸検査を行い，排卵日を 確定した。発情観察は朝夕の 1 日 2 回行い, 乗駕行動な どの明確な発情徵候を示した牛を発情と判定した。ま た，供試牛にはヒートマウントディテクターを装着し た。

\section{哺乳量と哺乳行動の調査}

哺乳量は分娩後約 1 週目から, 定期的に毎週 2 日間連 続して調查し，その平均值を 1 日当たり哺乳量とした。 測定方法は, 測定日の前日の 9 時に親子分離し， 16 時に 哺乳させた後, 再び親子分離を行い, 各測定日の 9 時と 16時の 1 日 2 回, 哺乳前後の子牛の体重差法により, 1 日当たり哺乳量を科量した。分婏後 30 日目の 1 日当たり 哺乳量は, その前後の測定日間に直線回帰を当てはめて 求めた。

哺乳行動は分娩後30日目の 9 時から，24時間連続して ビデオテープレコーダー(VTO-9000, ソニー)に記録し た後, 解析した。観察は, 同一牛舎内の約 $9 \mathrm{~m}^{2}$ の単房 に収容して行った。

哺乳行動は 1 日当たり哺乳回数, 総哺乳時間, 哺乳開 始時刻からつぎの哺乳開始時刻までのばらつきを示す哺 乳間隔時間の変動について分析した。哺乳間隔時間の変 動は, 変動係数で示した。

\section{分析方法}

初回排卵に影響を及ぼす要因と分娩後初回排卵までの 日数との関係は, 分婏後の初回排卵までの日数を目的変 数として, 各種要因の変数を説明変数とする変数減少法 による重回帰分析により解析した。説明変数として取り 上げた要因は, 産次 $\left(\mathrm{X}_{1}\right.$, 産), 分姢月 $\left(\mathrm{X}_{2}\right.$, 月 $)$, 母牛 の分婏直後の体重 $\left(\mathrm{X}_{3}, \mathrm{~kg}\right)$, 分婏直後体重と分娩後 30 日目の母牛の体重の差(以下 30 日目体重 $\mathrm{X}_{4}, \mathrm{~kg}$ ), 30 日 目に和ける 1 日当たりの哺乳量 $\left(\mathrm{X}_{5}, \mathrm{~kg}\right)$, 哺乳回数 $\left(\mathrm{X}_{6}\right.$, 回), 総哺乳時間 $\left(\mathrm{X}_{7}\right.$, 分), 哺乳間隔時間の変動 $\left(\mathrm{X}_{8}\right.$, \%) の 8 変数である。以上の各変数について基礎統計量 を求め, 2 次の効果を検討するために変数変換を行っ た。変数変換式は Table 1 に示した。ここでXは各測 定項目に対応する変数であり, Vは変数変換後の変数で ある。以上のように変換された変数を含む重回帰分析 は, 農林水産研究計算センターの「CMAP 会話型多変 量解析パッケージプログラム」により行った。

Table 1. Variable conversion and derived variables for curvelinear multiple regression analysis

\begin{tabular}{lll}
\hline \hline$V_{i j}=X_{i j}$ & $i=1,2, \ldots, 8$ & $j=1,2, \ldots, n^{*}$ \\
$V_{i+7 j}=X_{i j}-\bar{X}_{i}{ }^{2}$ & $i=1,2, \ldots, 8$ & $j=1,2, \ldots, n$ \\
$V_{i+17 j}=X_{i j}$ & $i=9$ & $j=1,2, \ldots, n$ \\
\hline
\end{tabular}

V : Derived variables, $\mathrm{X}$ : Original variables. Subscripts " $\mathrm{i}$ ” and “j” of original and derived variables show the variable number and detum number. Sources of original variable were explained in Table 3. ${ }^{*} \mathrm{n}=66$. 


\section{結 果}

\section{分婏後の卵巣機能回復}

重回帰分析に用いた，黒毛和種の初産から 9 産次にお ける延べ66頭の分婏後の初回排卵, 発情回帰までの日数 と排卯間隔日数を Table 2 に示した。初回排卵までの 日数は初, 2 産次牛でとくに長かった。発情回帰までの 日数も同様な傾向にあったが，産次間に有意な差は認め られず，全体の平均は48.0土10.8日であった。初回から 2 回目排卵までの日数は, 2 回から 3 回目排卵までの日 数に比べて有意 $(\mathrm{P}<0.01)$ に短かった。また，初回排卵 時に発情徵候を示した牛は全体で16.7\%にすぎなかった が，2 回目排卵時には93.8\%の牛が発情徵候を示した。
重回帰分析による分娩後の初回排卵までの日数に及ぼ す要因の解析

各変数の平均值などの基礎統計量を Table 3 に示し た。分婏直後体重は平均 $441.1 \mathrm{~kg}$ であった。30日目体 重は分婏直後体重に比べて平均 $9.2 \mathrm{~kg}$ 減少していたが, その範囲は +31.7〜-47.1 kg の広い範囲にばらついて いた。30日目の 1 日当たり哺乳量は $1.5 〜 7.2 \mathrm{~kg}$ の範囲 にあり, 哺乳回数, 総哺乳時間, 哺乳間隔時間の変動も ばらつきが大きかった。各産次に怙ける30日目の1日当 たり哺乳量は Fig. 1 に示すよらに，2〜 7 産次では平 均 $5.3 \sim 5.7 \mathrm{~kg}$ の範囲にあったが，8 産次以降は急激に 減少した。9 産次の哺乳量は, 初産牛とほぼ同程度であ った。

Table 2. The outline of the postpartum reproductive performance of cows which used in multiple regression analysis

\begin{tabular}{ccccc}
\hline Parity & $\begin{array}{c}\text { No. of } \\
\text { cows }\end{array}$ & $\begin{array}{c}\text { Interval from } \\
\text { calving to first } \\
\text { ovulation }\end{array}$ & $\begin{array}{c}\text { Interval from } \\
\text { calving to } \\
\text { first estrus }\end{array}$ & $\begin{array}{c}\text { Interval from ovulation to } \\
\text { the next ovulation }\end{array}$ \\
\hline 1 & 9 & $40.6 \pm 4.3^{\mathrm{a}}$ & $53.8 \pm 12.3$ & $14.0 \pm 4.4$ \\
2 & 14 & $41.9 \pm 7.0^{\mathrm{c}}$ & $52.9 \pm 11.1$ & $10.9 \pm 4.6$ \\
3 & 11 & $34.3 \pm 5.2$ & $45.4 \pm 8.9$ & $14.2 \pm 5.5$ \\
4 & 12 & $31.7 \pm 4.5$ & $47.2 \pm 8.0$ & $17.2 \pm 3.1$ \\
5 & 8 & $35.5 \pm 4.2$ & $48.6 \pm 13.2$ & $15.1 \pm 4.6$ \\
6 & 3 & $32.0 \pm 2.6$ & $41.7 \pm 7.5$ & $15.0 \pm 2.6$ \\
7 & 3 & $29.0 \pm 2.6^{\mathrm{b}}$ & $45.0 \pm 6.6$ & $16.0 \pm 4.6$ \\
8 & 4 & $27.8 \pm 4.5^{\mathrm{bd}}$ & $34.8 \pm 7.0$ & $11.0 \pm 7.6$ \\
9 & 2 & $29.5 \pm 9.2^{\mathrm{b}}$ & $45.0 \pm 8.5$ & $14.1 \pm 4.9$ \\
Total & 66 & $35.5 \pm 6.8$ & $48.0 \pm 10.8$ & $14.1 \pm 2 \pm 1.0$ \\
\hline
\end{tabular}

Values are mean \pm S. D. $a$ and $b, b$ and $c: P<0.05, c$ and $d: P<0.01$

Table 3. Fundamental statistics of original variables for multiple regression analysis

\begin{tabular}{|c|c|c|c|c|}
\hline & Mean & Minimum & Maximum & S. D. \\
\hline Parity $\left(\mathrm{X}_{1}\right)$ & 3.7 & 1 & 9 & 2.2 \\
\hline Month of parturition $\left(\mathrm{X}_{2}\right)$ & 6.4 & 1 & 12 & 3.4 \\
\hline Body weight at just after calving $(\mathrm{kg})\left(\mathrm{X}_{3}\right)$ & 441.1 & 315.0 & 561.0 & 55.4 \\
\hline Body weight loss $(\mathrm{kg})\left(\mathrm{X}_{4}\right)$ & -9.2 & -47.1 & +31.7 & 16.0 \\
\hline Milk yield at 30 postpartum days $(\mathrm{kg} /$ day $)\left(\mathrm{X}_{5}\right)$ & 5.1 & 1.5 & 7.2 & 1.3 \\
\hline Number of suckling events (times/day) $\left(\mathrm{X}_{6}\right)$ & 8.9 & 4 & 16 & 2.5 \\
\hline Total suckling time (min/day) $\left(\mathrm{X}_{7}\right)$ & 100.1 & 35.0 & 216.7 & 29.4 \\
\hline Fluctuations of suckling interval time $(\%)\left(\mathrm{X}_{8}\right)$ & 41.0 & 16.1 & 86.6 & 14.6 \\
\hline Days from calving to first ovulation (days) (Y) & 35.5 & 23 & 59 & 6.8 \\
\hline
\end{tabular}

Body weight loss from just after calving to 30 postpartum days. Number of suckling events, total suckling time and fluctuations of suckling interval were observing at 30 postpartum days and fluctuations of suckling interval time showed coefficient of variation. 


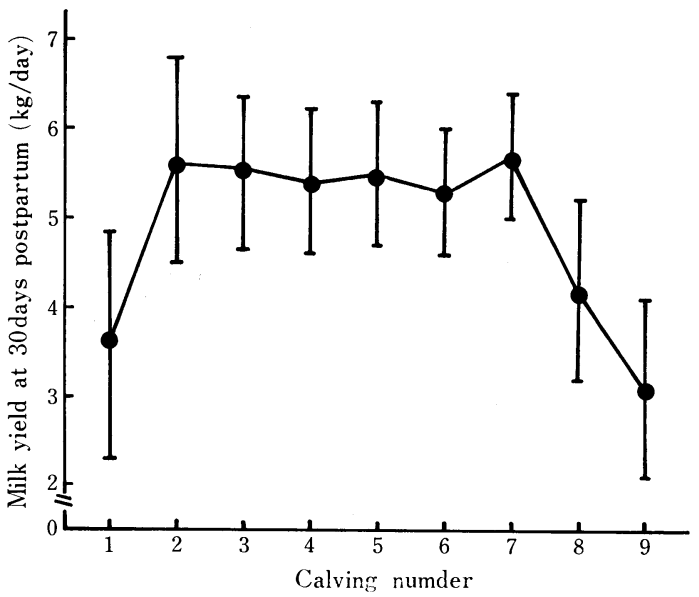

Fig. 1. Influences of parity for the milk yield at 30 days postpartum in Japanese Black cows.

変数相互間の相関関係を Table 4 に示した。初回排 卵までの日数と産次, 分婏直後体重, 30 日目体重との間 には有意な負の相関があり, 産次数, 分娩直後体重, 30
日目体重が大きくなるほど，初回排卵までの日数は小さ くなる傾向にあることを示している。哺乳量や哺乳回 数, 哺乳間隔時間の変動との間には正の相関が認められ たが，有意ではなかった。分婏直後の体重は産次の増加 にともなって重くなり, また, 哺乳量の増加は哺乳回数 や総哺乳時間を有意に減少させることを示している。 30 日目体重と哺乳量にも有意な負の相関が認められた。

誘導変数を含む $\mathrm{V}_{1}$ から $\mathrm{V}_{16}$ までの16変数について, 変数減少法による重回帰分析の 経過をTable 5 に示し た。自由度調整後の寄与率 $\left(100 \mathrm{R}^{*}\right)$ は $62.6 \%$ から最高 $65.3 \%$ 示し, その後 $63.8 \%$ に若干低下した。変数減少 の過程で $V_{11}$ (分娩直後体重), $V_{12}$ (30日目体重), $V_{13}$ (哺 乳量), $\mathrm{V}_{14}$ (哺乳回数), $\mathrm{V}_{16}$ (哺乳間隔時間の変動) など の 2 次の変数は早くから除去されたが, 産次と総哺乳時 間の 2 次の変数は全過程を通じて保持された。最終的に は自由度調整後の寄与率が $63.8 \%$ 示す重回帰式が得ら れた。Table 6 の分散分析表に示すように, 回帰成分は 残差よりも $0.1 \%$ 水準で有意に大きかった。Table 7 は 得られた重回帰式の偏回㷌係数と相対重要度を示した。 この重回帰式は逆変換して誘導変数を含まない以下の形

Table 4. Correlation matrices of original variables

\begin{tabular}{|c|c|c|c|c|c|c|c|c|}
\hline Variable & $\mathrm{X}_{2}$ & $\mathrm{X}_{3}$ & $\mathrm{X}_{4}$ & $\mathrm{X}_{5}$ & $\mathrm{X}_{6}$ & $\mathrm{X}_{7}$ & $\mathrm{X}_{8}$ & $\mathrm{Y}$ \\
\hline $\mathrm{X}_{1}$ & 0.161 & $0.550 * *$ & 0.068 & -0.010 & 0.110 & $0.333^{* *}$ & 0.126 & $-0.586^{* *}$ \\
\hline $\mathrm{X}_{2}$ & & -0.064 & 0.196 & $-0.326^{* *}$ & 0.098 & 0.144 & -0.009 & -0.214 \\
\hline $\mathrm{X}_{3}$ & & & -0.213 & $0.245^{*}$ & -0.172 & -0.054 & 0.096 & $-0.430^{* *}$ \\
\hline $\mathrm{X}_{4}$ & & & & $-0.384 * *$ & $0.307^{*}$ & $0.353^{* *}$ & 0.022 & $-0.268^{*}$ \\
\hline $\mathrm{X}_{5}$ & & & & & $-0.415^{* *}$ & $-0.393^{* *}$ & -0.198 & 0.224 \\
\hline $\mathrm{X}_{6}$ & & & & & & $0.813^{* *}$ & $0.399^{* *}$ & 0.216 \\
\hline $\mathrm{X}_{7}$ & & & & & & & $0.306^{*}$ & -0.140 \\
\hline $\mathrm{X}_{8}$ & & & & & & & & $0.1 \varepsilon 0$ \\
\hline
\end{tabular}

Source of original variable were explained in Table $3 .^{*}: \mathrm{P}<0.05,{ }^{* *}: \mathrm{P}<0.01$.

Table 5. Multiple regression analysis by backward procedure

\begin{tabular}{ccccccccccccccccccc}
\hline \hline Step & $\mathrm{V}_{1}$ & $\mathrm{~V}_{2}$ & $\mathrm{~V}_{3}$ & $\mathrm{~V}_{4}$ & $\mathrm{~V}_{5}$ & $\mathrm{~V}_{6}$ & $\mathrm{~V}_{7}$ & $\mathrm{~V}_{8}$ & $\mathrm{~V}_{9}$ & $\mathrm{~V}_{10}$ & $\mathrm{~V}_{11}$ & $\mathrm{~V}_{12}$ & $\mathrm{~V}_{13}$ & $\mathrm{~V}_{14}$ & $\mathrm{~V}_{15}$ & $\mathrm{~V}_{16}$ & Mult-R & $100 \mathrm{R} *$ \\
\hline $\mathrm{l}$ & $*$ & $\mathrm{n}$ & $*$ & $*$ & $*$ & $\mathrm{n}$ & $\mathrm{n}$ & $\mathrm{n}$ & $*$ & $\mathrm{n}$ & $\mathrm{n}$ & $*$ & $*$ & $\mathrm{n}$ & $*$ & $\mathrm{n}$ & 0.8475 & 62.63 \\
2 & $*$ & $\mathrm{n}$ & $*$ & $*$ & $*$ & $\mathrm{n}$ & $\mathrm{n}$ & $\mathrm{n}$ & $*$ & $\mathrm{n}$ & $\mathrm{n}$ & & $\mathrm{n}$ & $\mathrm{n}$ & $*$ & $\mathrm{n}$ & 0.8473 & 63.33 \\
3 & $*$ & $\mathrm{n}$ & $*$ & $*$ & $*$ & $\mathrm{n}$ & $\mathrm{n}$ & $\mathrm{n}$ & $*$ & $\mathrm{n}$ & $\mathrm{n}$ & & & $\mathrm{n}$ & $*$ & $\mathrm{n}$ & 0.8465 & 63.87 \\
4 & $*$ & $\mathrm{n}$ & $*$ & $*$ & $*$ & $\mathrm{n}$ & $\mathrm{n}$ & $\mathrm{n}$ & $*$ & $\mathrm{n}$ & $\mathrm{n}$ & & & & $*$ & $\mathrm{n}$ & 0.8457 & 64.33 \\
5 & $*$ & $\mathrm{n}$ & $*$ & $*$ & $*$ & $\mathrm{n}$ & $\mathrm{n}$ & $\mathrm{n}$ & $*$ & $\mathrm{n}$ & $\mathrm{n}$ & & & & $*$ & & 0.8444 & 64.80 \\
6 & $*$ & $\mathrm{n}$ & $*$ & $*$ & $*$ & $\mathrm{n}$ & $\mathrm{n}$ & $\mathrm{n}$ & $*$ & $\mathrm{n}$ & & & & & $*$ & & 0.8427 & 65.11 \\
7 & $*$ & & $*$ & $*$ & $*$ & $\mathrm{n}$ & $\mathrm{n}$ & $\mathrm{n}$ & $*$ & $\mathrm{n}$ & & & & & $*$ & & 0.8405 & 65.31 \\
8 & $*$ & & $*$ & $*$ & $*$ & $\mathrm{n}$ & $\mathrm{n}$ & & $*$ & $\mathrm{n}$ & & & & & $*$ & & 0.8380 & 64.44 \\
9 & $*$ & & $*$ & $*$ & $*$ & $\mathrm{n}$ & $\mathrm{n}$ & & $*$ & & & & & & $*$ & & 0.8260 & 63.80 \\
& & & & & & & & & & & & & & & & & &
\end{tabular}

Partial regression coefficients retained were indicated “*” as significance and " $n$ " as no significance. 100R*: Multiple correlation coefficent adjusted by degrees of freedom. 
Table 6. Variance analysis table for multiple regression analysis on the interval from calving to first ovulation

\begin{tabular}{lcrc}
\hline \multicolumn{1}{c}{ S. V. } & D. F. & M. S. & F \\
\hline Regression & 9 & 259.307 & $15.301^{* *}$ \\
Residual & 57 & 16.947 & \\
Total & 65 & & \\
\hline
\end{tabular}

** : $\mathrm{P}<0.01$

Table 7. Partial regression coefficients for the interval from calving to first ovulation in Japanese Black cows

\begin{tabular}{crrrc}
\hline $\begin{array}{c}\text { Independent } \\
\text { variable }\end{array}$ & B & Std. B & T value & $\begin{array}{c}\text { Relative } \\
\text { importance }(\%)\end{array}$ \\
\hline $\mathrm{V}_{1}$ & -1.842 & -0.583 & -4.914 & 30.9 \\
$\mathrm{~V}_{3}$ & -0.036 & -0.291 & -2.829 & 10.2 \\
$\mathrm{~V}_{4}$ & -0.112 & -0.261 & -3.039 & 11.8 \\
$\mathrm{~V}_{5}$ & 2.001 & 0.352 & 3.688 & 17.4 \\
$\mathrm{~V}_{6}$ & 0.521 & 0.191 & 1.943 & 4.8 \\
$\mathrm{~V}_{8}$ & 0.103 & 0.220 & 2.179 & 6.1 \\
$\mathrm{~V}_{9}$ & 0.364 & 0.331 & 2.982 & 11.4 \\
$\mathrm{~V}_{15}$ & -0.001 & -0.209 & -2.418 & 7.5 \\
Constant & 37.157 & & 6.542 & \\
\hline
\end{tabular}

B: Partial regression coefficient, Std. B: Standard Partial regression coefficient.

に書き直すことができる。

$$
\begin{aligned}
& \mathrm{Y}= 37.157-1.842 \mathrm{X}_{1}-0.036 \mathrm{X}_{3}-0.112 \mathrm{X}_{4} \\
&+2.001 \mathrm{X}_{5}+0.521 \mathrm{X}_{6}+0.103 \mathrm{X}_{8} \\
&+0.364\left(\mathrm{X}_{1}-3.7\right)^{2}-0.001\left(\mathrm{X}_{7}-100.1\right)^{2} \\
& \mathrm{Y}: \text { 分婏後の初回排卵までの日数, } \mathrm{X}_{1}: \text { 産次, } \\
& \mathrm{X}_{3}: \text { 分婏直後の母牛体重, } \mathrm{X}_{4}: 30 \text { 日目体重, } \\
& \mathrm{X}_{5} \text { : 哺乳量, } \mathrm{X}_{6}: \text { 哺乳回数, } \mathrm{X}_{7}: \text { 総哺乳時間, } \\
& \mathrm{X}_{8} \text { : 哺乳間隔時間の変動 }
\end{aligned}
$$

分娩後の初回排卵までの日数に及ぼすこれら要因の相 対重要度は, 産次 $(42.3 \%)>$ 哺乳量 $(17.4 \%)>30$ 日目体 重 $(11.8 \%)>$ 分婏直後体重 $(10.2 \%)>$ 総哺乳時間 $(7.5$ $\%)>$ 哺乳間隔時間の変動 $(6.1 \%)>$ 哺乳回数 $(4.8 \%)$ と なり，産次の効果が最も大きかった。また，初回排卵ま での日数は哺乳量や哺乳回数, 哺乳間隔時間の変動が大 きいほど遅延するが，分婏直後体重や30日目体重が増加 するほど短縮することが，この回帰式は示している。

得られた重回帰式の性質を調べるために, 各変数を測 定值の範囲で変化させ, その推定值を求めた。産次を 1 から 9 まで変化させ, その他の変数に平均值を代入し, 分婏後の初回排卵までの日数に及ぼす産次の効果を検討 した結果は, Fig. 2 に示したょうに，2次の関数で表

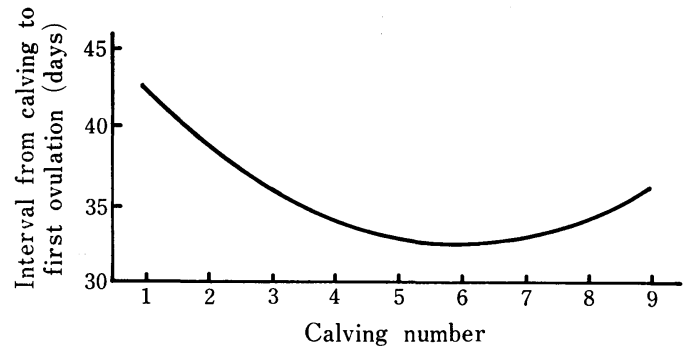

Fig. 2. Partial regression of first postpartum ovulation on calving number. Estimates of first postpartum ovulation from 1st to 9th calving number indicated by quadratic curve on condition that other variables took mean values.

される。初産牛の初回排卵までの日数は42.6日と最も大 きな值を示し，その後漸減して 6 産次には 32.4 日と最小 值を示した後，9産次まで再び漸増した。9 産次の初回 排卵日数は 36.0 日と推定された。同様に総哺乳時間も Fig. 3 に示すように, その平均值 (100.1分)を最大值と する 2 次の関係が認められ，総哺乳時間が長くてもある 


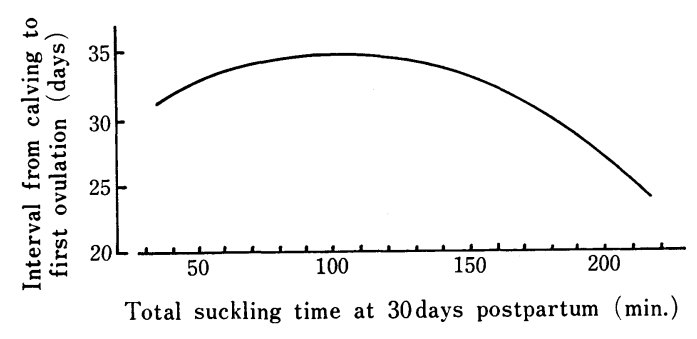

Fig. 3. Partial regression of first postpartum ovulation on total suckling time. Estimates of first postpartum ovulation from 35.0 to 216.7 total suckling time (min) were displayed by quadratic curve on condition that other variable took mean values.

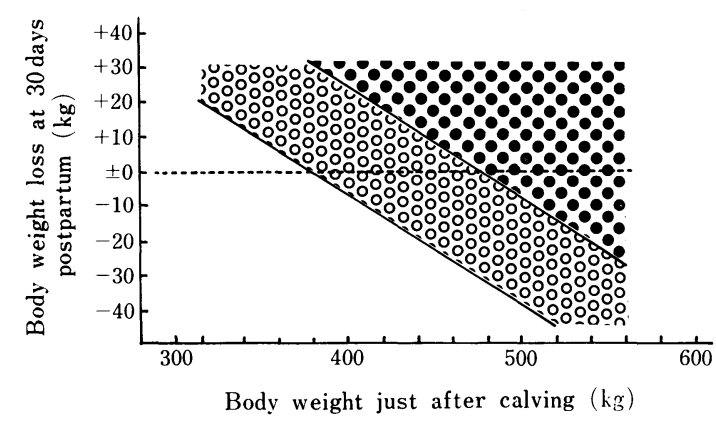

Fig. 4. The combination condition of body weight just after calving and body weight loss at 30 days postpartum for the occurrence of first ovulation within 40 days postpartum.

$$
\begin{aligned}
& \because: \text { Calving number was first. } \\
& \begin{array}{ll}
\circ & 0 \\
\circ & \circ
\end{array} \text { calving number was second. }
\end{aligned}
$$

\section{いは短くても初回排卵は遅延した。}

次に, 分婏後 40 日以内に初回排卵が起こる条件を推定 するため, 分婏直後体重と 30 日目体重との関係につい て, 産次の変化も考慮して推定した。他の変数には平均 值を代入した。初産牛で40日以内に初回排卵が起こる分 婏直後体重と30日目体重の組合せは Fig. 4 に示すよう に

$\mathrm{Y}=-0.321 \mathrm{X}+153.12(\mathrm{Y}: 30$ 日目体重, $\mathrm{X}$ : 分娩直 後体重)

で示される直線回帰式を下限とする領域となる。2 産次 においてはその回帰係数は変わらないものの, 産次の効 果が加わるため定数は121.94に減少し, 初産牛に比べて 体重の条件は緩和される。また， 3 産次以降になるとす べての体重の変動值内で 40 日以内の初回排卵が可能とな

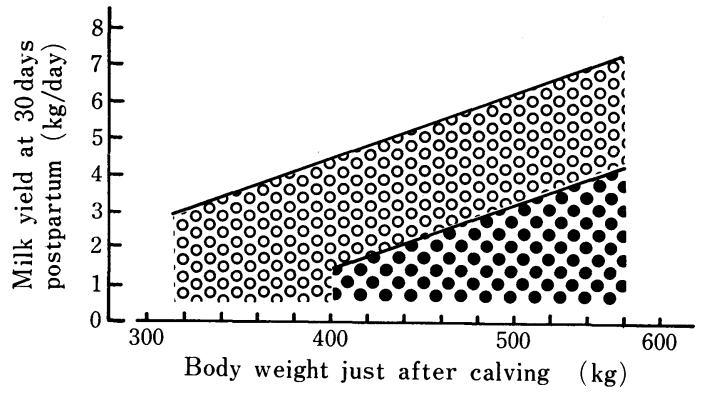

Fig. 5. The combination condition of body weight just after calving, milk yield and number of suckling events for the occurrence of first ovulation within 40 days postpartum in the case of the first calving number.

$\because:$ =suckling events were 4 times.

$\begin{array}{ll}0 & 0 \\ 0 & 0\end{array}=$ Suckling events were 16 times.

る。

さらに, 初産牛に拈いて分婏後 40 日以内に初回排卵が 起こる分婏直後体重, 哺乳量と哺乳回数との関係をFig. 5 に示した。哺乳回数が16回のときには

$\mathrm{Y}=0.018 \mathrm{X}-5.81$ ( $\mathrm{Y}$ : 哺乳量, $\mathrm{X}$ : 分娩直後体重) で示される直線回帰式を上限とする領域となるが，哺乳 回数が 4 回になるとその領域が拡大し, 哺乳回数が16回 の場合に比べて約 $3 \mathrm{~kg}$ 乳量が多くても可能になること を示している。また, 哺乳量が同一であれば, 哺乳回数 が減少することにより, 分娩直後体重はより軽くてもよ いことを示唆している。なお，これらの要因による制限 は産次の増加にともなって減少してくる。

\section{考察}

牛における分娩後の発情回帰は, 黒毛和種を含せおよ そ50日との報告が多い(Boyed, 1977; 高橋ら，1979；居 在家ら，1983; 岡野ら，1984）。本試験で供試した分婏 から初回排卵までの日数, 発情回㷌日数は, これらの報 告の值に類似の值であった。また, 初回から回目排卵ま での各排卵間隔日数や各排卵時の発情発現割合も多くの 報告 (Hinshelwood et al., 1982; Basidas et al., 1984; 鈴木・佐藤, 1984 ；居在家ら，1984）とほぼ一致してい た。したがって，本試験で得られた分娩後の卵巣機能回 復は, 平均值的な值であることが示唆された。

分娩後の卵巣機能回復と産次との関係について, 初産 牛ではとくに，分娭後の初回排卵や発情回帰が遅れると の報告が多い(Wiltbank and Cook, 1958; 高橋ら, 
1979；居在家ら，1984）。本試験で得られた重回帰式で も同様の傾向にあることが認められ, しかも, 産次の効 果が最も大きいことが示唆された。また，加齢による卵 宩機能の低下は産歴と年秢, 飼養管理状態の影響を受け (Erickson et al., 1976; 山内, 1978; 岡野ら, 1984), 何産次ごろから卵巣機能の低下が起こるかを決定するこ とは困難である。本試験で重回帰分析した結果では，7 産次以降になると初回排卵までの日数が増大傾向に転じ たことから，放牧牛の加㱓による卵巣機能の低下は，7 産次目ころから始まるものと推定された。この分析の結 果は, Table 2 に示した $7 \sim 9$ 産次における, 実際の 初回排卵をでの日数とは必ずしも一致していなかった が, これは Fig. 1 に示すように, 哺乳量が 8 産以降急 激に減少するため, 初回排卵に及ぼす哺乳量の抑制効果 が大幅に減少したためと考えられた。

初産牛の分娭直後体重は 2 産次以降に比べてとくに軽 く,このことが初産牛で分乨後の初回排卵までの間隔を 増大させていると考学られている（居在家ら，1984）。 Peters and Riley(1982) も分婏後の母牛の体重が軽いほ ど卵巣機能回復は遅れる傾向にあることを示唆してい る。本試験の供試牛も, 分姢直後体重は産次の増加にと もなって重くなる有意な相関関係 $(\mathrm{p}<0.01)$ にあった。 以上のことから, 分娩後の初回排卵に及ぼす産次の効果 と分婏直後体重の効果とを明確に区分することは, これ まで困難であった。しかし, 本試験での重回帰分析の結 果, 分乨後の初回排卵に及ぼす産次の効果は 2 次の非線 形性，体重の効果は線形性の回㷌モデルで示されたこと から，両者の関係は完全には一致して和らず，これまで 分離してとらえることが困難であった産次とのものの効 果を, 初めてとらえることができたものと推察された。

分婏直後の体重や分婏前後の栄養状態, とくに分婏後 の栄養状態が卵巣機能回復に大きく関与し, 低栄養では 卵巣機能回復が遅延する傾向を示すことが報告されてい る (Dunn et al., 1969; 鈴木・佐藤, 1982; 岩崎, 1986)。 Carstairs et al. (1980) は，栄着水準の差による初回排卵 までの日数には差がなかったが, 重回帰分析の結果から は栄養水準が高いほど初回排卯までの日数は短縮する, との結果を得た。一方, 黒田ら(1979)は, 2 ～産の黑 毛和種を用いて, 分婏前後の TDN 給与水準と発情回㷌 日数との関係について検討した結果, TDN 給与水準を 異にする区間と発情回帰日数に有意差は認められなかっ たと報告している。これらの報告では, 産次や試験開始 時の体重, 給与飼料構成などが大きく異なり, 栄養水準 と分娩後の卵巣機能回復との関係は一律に比較できない
ものと推察された。林ら(1983)は, 牛の体重の増減はそ のときの栄養状態を示す指標となり, 繁殖成績への効果 をより直接的に評価できると述べている。そこで栄養状 態を示す指標としての体重の変化から, 分娩後の初回排 卵に及ぼす栄養状態の影響を検討した。哺乳量や哺乳回 数などに平均值を代入し, 分娩後の初回排卵に及ぼす分 娩直後体重と 30 日目体重との組合せを比較した結果, 初 産牛で分娩後 40 日以内に初回排卵するには, 分娩直後体 重が $378 \mathrm{~kg}$ 以上あることが必要とされた。分娩後30日 目体重の条件は, 分婏直後体重が増加するにともないそ の範囲も広くなったが，30日目体重が $27 \mathrm{~kg}$ 以上減少す ると, 初産牛では 40 日以内の初回排卵は不可能であるこ とが示唆された。本試験で供試した初産牛の分娩直後体 重は平均 $366.8 \mathrm{~kg}$ であり, 福原ら（1973）が示した発育 曲線のほぼ平均的な発育の範囲にあった。初産牛におけ る体重の効果だけを考えると育成期を高栄養で飼養し, 体重の増加を図ることは, 分娩後の初回排卵を早める一 つの手段であるが, 連産性の維持や生涯生産性の点から は問題のあることが, 鈴木ら(1985)によって指摘されて いる。また, 分娩後の栄養状態は個体差も大きいが, 初 産牛の体重では分娩後早い時期に初回排卵するのは, か なり困難であるものと推察された。一方, 産次が増加す るにともない産歴の効果が加わるために， 3 産次以降に なると観察したすべての体重の組合せで分娩後 40 日以内 の初回排卵が可能となり, 栄養水準の変化に適応する範 用が広がることが示晙された。黑田ら（1979）は, 若㸳 牛は栄養不足に敏感であるが, 壮㱓牛ではかなりの低栄 養でも適応し得ると推察している。また, 岩崎（1986） も同様の試験結果を報告している。本試験で得られた分 娩後の初回排卵に及ぼす体重の効果からも, 産次の増加 にともなって同様の傾向にあることが示唆され, 黒田ら (1979)，岩崎 (1986)の試験結果が支持された。

Stevenson and Britt (1980) は乳牛において, 内分泌 の動態の観点から Estradiol-17 $\beta, \mathrm{LH}$, Glucocorticoids, 発育卵胞の大ささなどを目的変数として初回排卵までの 日数を予測する適合度の高い重回帰式を得ている。分婏 後の初回排卵が原則的にはこれらのホルモン動態によっ て影響を受けることは明らかである。しかし, 哺乳刺激 によって律動的な LH の分泌が抑制されるため, 卵巣機 能回復も抑制されることなどが示唆 (Hinshelwood et al, 1982）されていることなどから，今姢後の卵巣機能回復 には哺乳量や哺乳刺激などが, それらのホルモン動態に 直接的にも関連しているものと推察されている（Schallenberger and Walters, 1985)。 
また，乳量と分娩後の繁殖機能回復との関係について は, 乳牛で多くの解析がなされているが, 乳量の増加に ともない発情回帰が遅れるとする報告 (Laben et al., 1982 ; Hillers et al., 1984） と, 必ずしも関連しないと する報告(井上・鈴木，1981)があり，一致した結論は得 られていない。これには乳量の増加による栄養状態の変 化も影響していると推察され, Hansen et al. (1982) は 低栄養状態のときにのみ乳量と繁殖性の関連性が認めら れると報告している。肉用牛に㧍ける哺乳量と卵巣機能 回復との関係についてはこれまで明らかにされていない が, 島田ら(1986)は黒毛和種で産子の増体量を乳量の指 標とすると，30日齢までの乳量が増加，あるいは減少い ずれの方向に変化しても, 発情回㷌が遅れる可能性のあ ることを示唆している。また乳牛では，乳量がほぼ同一 であっても, 産子数, 哺乳, 搾乳などの違いによって卵巣 機能回復は影響されることが報告されている（Wagner and Li., 1982)。そこで本試験で得られた重回帰式から 初回排卵に及ぼす分娩直後体重, 哺乳量, 哺乳回数の相 互関係について検討した。その結果, 哺乳量, 哺乳回数 の増加は卵巣機能回復を抑制し, とくに分娩直後体重が 軽いほど，その抑制効果は相対的に強くなることが示唆 された。これらの関係は線形性であり，産子の増体量を 指標とした島田ら(1986)の報告とは必ずしも一致してい なかった。

哺乳量は産子の発育量と密接な関係にあることから， 放牧飼養などでは子牛の発育を改善するために，哺乳量 の多い母牛を選抜していく必要がある。このような哺乳 量の増加によって卵巣機能回復の抑制効果が増幅される が，1日当たりの哺乳回数を人為的に制限することによ り，その抑制効果を相対的に軽減できることが示唆され た。哺乳回数の制限により, 卵巣機能回復を促進できる ことは報告されている (Reeves and Gaskins, 1981; Bastidas et al., 1984；鈴木・佐藤，1984）。また，この 重回㷌式から, 哺乳回数の制限による卵巣機能回復は, 体重が軽くて哺乳量が多い牛で, 産次ではとくに初, 2 產次牛でその促進効果が期待できるものと考えられた。

自然哺乳では哺乳間隔時間のばらつきが大きく, 卵巣 機能回復を抑制していることが本試験の解析の結果, 明 らかになった。そこで, 哺乳回数をある特定の時間帯に 制限することによって, 哺乳間隔時間の変動を減少させ ることが可能になり，その副次的効果も卵巣機能回復の 促進に加わるものと推察された。

総哺乳時間が分娩後の初回排卵に及ぼす影響には 2 次 の関係が認められた。総哺乳時間は哺乳回数と正の, 哺
乳量とは負の有意な相関を示し, さらに, 哺乳量と哺乳 回数とは負の相関関係にあった。しかし, 総哺乳時間は 哺乳回数によって規制される従属性の事象と考えられる ことから, 基本的には分婏後の初回排卵に及ぼす哺乳量 と哺乳回数の両者の相互効果が表面的に総哺乳時間とし て表されているものと推察された。その結果, 哺乳量が 増加すると哺乳回数は減少するために, 初回排卵に及ぽ す抑制効果は相対的に減少する。一方, 哺乳量が減少す ると哺乳回数は増加するが, 哺乳量の減少による初回排 卵に及ぼす抑制効果の方が大きく減少する。その結果, 哺乳量と哺乳回数のこれら両者の関係が, 総哺乳時間が 長くても, あるいは短くても分娩後の初可排卵までの日 数が短くなる，2次の関係となって示されたものと推察 された。

以上の結果, 自然哺乳させている状態での肉用牛にお ける, 分姢後の初回排卵までの日数に及ぼす産次, 体 重, 哺乳量や哺乳回数などの特性と, その相互の関連性 が明らかとなった。

\section{Referencez}

Bastidas P, Troconiz J, Verde O, Silva O (1984) Effect of restricted suckling on ovarian activity and uterine involution in Brahman cows. Theriogeno$\log y$ 21: $525-532$.

Boyed $\mathrm{H}$ (1977) Anoestrus in cattle. Vet Rec 100: 150-153.

Bulman OC, Lamming GE (1978) Milk progesterone levels in relation to conception, repeat breeding and factors influencing acyclicity in dairy cows. $J$ Reprod Fert 54: 447-458.

Carstairs JA, Morrow DA, Emery RS (1980) Postpartum reproductive function of dairy cows as influenced by energy and phosphorus status. J Anim Sci 51: 1122-1130.

Dunn TG, Ingalls JE, Zimmerman DR, Wiltbank JN (1969) Reproductive performance of 2-year old Hereford and Angus heifers as influenced by preand post-calving energy intake. J Anim Sci 29: 719-726.

Erickson BH, Reynolds RA, Murphree RL (1976) Ovarian characteristics and reproductive performance of the aged cow. Biol Reprod 15: 555560.

Fukuhara R, Obata T, Kihara Y (1973) Growth and growth patterns of Japanese cattle on pasture 1 . Estimation of the growth curves and determination of the size ranges of normal growth. Bull Chugoku Natl Agri Exp Stn Series B 20: 1-50 (in Japanese).

Hansen PJ, Baik DH, Rutledge JJ, Hauser ER (1982) 
Genotype X environmental interactions on reproductive traits of bovine females. II. Postpartum reproduction as influenced by genotype, dietary regimen, level of milk production and parity. $J$ Anim Sci 55: 1458-1472.

Hayashi T, Nagamine Y, Nishida A (1983) Multiple regression analysis of factors affecting open days of dairy cattle. Jpn J Anim Reprod 29: 13-19 (in Japanese).

Hillers JK, Senger PL, Darlington RL, Fleming WN (1984) Effects of production, season, age of cow, days dry, and days in milk on conception to first service in large commercial dairy herds. J Dairy Sci 67: 861-867.

Hinshelwood MM, Hansen PJ, Hauser ER (1982) Short estrous cycles in postpartum cows as influenced by level of milk production, suckling diet, season of calving and interval to first estrus. Theriogenology 18: 383-392.

Inoue G, Suzuki I (1981) Milk production and fecundity in the cow. In: Symposium on lactation and reproduction. Jpn J Anim Reprod 27: 31-35 (in Japanese).

Iwasaki K (1986) Energy metabolism and efficincy of utilization of energy in pregnant Japanese black cattle. Bull Nat Inst Anim Ind 45: 25-92 (in Japanese).

Izaike Y, Okano A, Shioya Y, Oishi T (1983) Factors affecting interval to first postpartum estrus and conception rate in Japanese black cows. Bull Chugoku Natl Agri Exp Stn Series B 27-9-18 (in Japanese).

Izaike Y, Okano A, Shimada A, Oishi T (1984) Relationship between postpartum reproductive performance and calving number in beef cows. Jpn J Anim Reprod 30: 206-210 (in Japanese).

Kuroda A, Tsukamoto A, Kanayama A, Mizoguchi Y, Kanaga Y (1979) Cooperative studies on the practical feeding levels of fed before and after calving in Japanese black cows. Influences of pre- and post-calving TDN levels on cow's reproductive performance. Report Cooper Res KinkiChugoku Reg 7: 13-20 (in Japanese).

Laben RL, Shanks R, Berger PJ, Freeman AE (1982) Factors affecting milk yield and reproductive performance. J Dairy Sci 65: 1004-1015.

Okano A, Shimada K, Izaike Y, Oishi T (1984) Reproductive performance of Japanese black cows in their lifetimes. Jpn J Zootech Sci 55: 458-464 (in Japanese).
Peters AR, Riley GM (1982) Milk progesterone profiles and factors affecting postpartum ovarian activity in beef cows. Anim Prod 34: 145-153.

Reeves JJ, Gaskins CT (1981) Effect of once-a-day nursing on rebreeding efficiency of beef cows. $J$ Anim Sci 53: 889-891.

Schallenberger E, Walters DL (1985) Endocrine mechanisms contributing to postpartum anestrus in daily and beef cattle. In: Endocrine causes of seasonal and lactational anestrus in farm animals. (Ellendorff F, Elsaesser F eds.), Martinus Nijhoff Publishers, Dordrecht. pp 206-220.

Shimada K, Izaike Y, Okano A, Oishi T (1986) Effects of year, season, parity, sex of calf and milk yield on postpartum reproductive performance in grazing Japanese black cows. Jpn J Zootech Sci 57: 1038-1040 (in Japanese).

Stevenson JS, Britt JH (1980) Models for prediction of days to first ovulation based on changes in endocrine and nonendocrine traits during the first two weeks postpartum in Holstein cows. J Anim Sci 50: 103-112.

Suzuki O, Sato M (1984) Effects of once-daily suckling and twice-daily suckling on postpartum reproductive performance of beef cows and on growth and ingestive behavior of their calves. Jpn J Anim Reprod 30: 39-45 (in Japanese).

Suzuki O, Sato M, Sakai Y (1985) Growth, puberty and subsequent calf production of Japanese black cows reared on different feeding regimes. Bull Natl Grassl Res Inst 32: 14-26 (in Japanese).

Takahashi M, Kikuchi T, Takizawa S, Kyuma T (1979) Onset of estrus following calving in spring in Japanese black cows. Bull Tohoku Natl Agric Exp Stn 60: 63-72 (in Japanese).

Wagner WC, Li PS (1982) Influence of adrenal corticosteroids on postpartum pituitary and ovarian function. Current Top Vet Med Anim Sci 20: 197-219.

Wiltbank JN, Cook AC (1958) The comparative reproductive performance of nursed cows and milked cows. J Anim Sci 17: 640-648.

Wyatt RD, Gould MB, Totusek R (1977) Effects of single vs simulated twin rearing on cows and calf performance. J Anim Sci 45: 1409-1414.

Yamauchi S (1978) Ageing and sexual function -General discussions and particular reference to the case in cattle-. Jpn J Zootech Sci 49: 387-399 (in Japanese). 
要約

黒毛和種66頭を用いて, 分娩後の初回排卵までの日数に及ぼす産次, 体重, 哺乳量, 哺乳刺激の影 響について重回帰分析により検討した結果，寄与率が $63.8 \%$ の下の重回帰式が得られた。

$$
\begin{aligned}
\mathrm{Y}= & 37.157-1.842 \mathrm{X}_{1}-0.036 \mathrm{X}_{3}-0.112 \mathrm{X}_{4} \\
& +2.001 \mathrm{X}_{5}+0.521 \mathrm{X}_{6}+0.103 \mathrm{X}_{8} \\
& +0.364\left(\mathrm{X}_{1}-3.7\right)^{2}-0.001\left(\mathrm{X}_{7}-100.1\right)^{2}
\end{aligned}
$$

$\mathrm{Y}$ : 分婏後の初回排卵までの日数, $\mathrm{X}_{1}$ : 産次, $\mathrm{X}_{3}$ : 分娩直後の母牛体重,

$\mathrm{X}_{4}: 30$ 日目体重, $\mathrm{X}_{5}: 30$ 日目の 1 日当たり哺乳量, $\mathrm{X}_{6}: 30$ 日目の 1 日当 たり哺乳回数, $\mathrm{X}_{7}: 30$ 日目の 1 日当たり総哺乳時間, $\mathrm{X}_{8}$ : 哺乳間隔時間 の変動

これら要因の相対重要度は, 産次 $>$ 哺乳量 $>30$ 日目体重 $>$ 分娩直後体重 $>$ 総哺乳時間 $>$ 哺乳間隔時 問の変動 >哺乳回数の順であった。初回排卵までの日数に及洔す産次の効果は, 6 産次を最小值とす る 2 次関数で, また, 総哺乳時間の効果は平均值 (100.1分)を最大值とする 2 次関数で表された。さ らに, 哺乳量や哺乳回数の増加は分婏後の初回排卵までの日数を増大させ, また, 分娩後の体重の変 動によっても大きく影響されることが明らかとなった。 